\title{
The Imperial Cancer Research Fund
}

$\mathrm{T}^{\mathrm{H}}$ HE thirteenth report of the British Empire Cancer Campaign was dealt with in NATURE of December 12. We have now received the thirtyfourth annual report of the Imperial Cancer Research Fund*. The Fund began in 1902, and its activities have been in the main devoted to the experimental study of cancer in its own laboratories; besides being one of the first, it has earned its position as one of the leading organizations for the study of malignant disease, and the high quality of the work done under its first two directors, Dr. E. F. Bashford and Dr. J. A. Murray, has been generally recognized. The Fund is under the direction of the Royal Colleges of Physicians and Surgeons, and it has until now been housed in their Examination Halls on the Embankment and in Queen Square, London; more room is now needed, and a new building is to be put up at Mill Hill with plenty of spare land leased from the Medical Research Council. When the cause and cure of cancer have been ascertained, the Royal Colleges will have the duty of diverting the endowment to some other line of medical research; meanwhile, there is no reason for supposing that the new director, Dr. W. E. Gye, and his assistants will not have their hands full with the multiplicity of work in various directions into which modern cancer research has developed.

The present report details sound progress, though Dr. Gye has nothing sensational to announce. He stresses the necessity of distinguishing between two categories of 'causes' of cancer which are sometimes confused. There is first the nature of the intrinsic cellular change which confers upon a cell the property of malignancy, that is, its dissociation from functional relationships with the rest of the body and its capacity for continuous and autonomous growth. The factor which produces this change resides in the cell, and cannot be attributed to external agents; it is the proximate cause of cancer and we know little about it, but seeing that in essential characters all malignant cells are alike, we may surmise that the nature of the change is always the same. It may, however, be preceded by a number of remote causes of diverse nature which bring about the fundamental intracellular change-radium, X-rays, many chemical substances, etc.-and of these we now have fairly extensive knowledge which, if it tells us little about the nature of malignancy, enables us on one hand to prevent some cancers in man, and on the other to produce fresh tumours in animals

* Thirty-fourth Annual Report 1935-1936 of the Imperial Cancer Research Fund. Pp. 44. (London: Imperial Cancer Research Fund, 1936.) for experimental study. Another general point brought out in several places in the report is the importance of constitution or diathesis, which comes out clearly now that more precise methods of starting tumours are available, and it seems that this concerns particular organs rather than the animal as a whole.

Much attention has naturally been paid to the virus tumours which can be transferred from one animal to another by cell-free extracts. Attempts to repeat McIntosh's observation that fowl tumours produced by chemicals could be transmitted by filtrates all failed, but it was found that such cellfree extracts injected into rabbits would, equally with tumour tissue, excite the appearance in the blood of a capacity to neutralize the virus of the Rous sarcoma. Since the same chemical (tar, dibenzanthracene, etc.) will induce tumours in mammals as well as birds, it seems likely that something like a virus can be evoked from all cancers. The whole question is at the moment extremely complicated. The effect of radium has also been further investigated, especially by the study of its action on various enzyme systems : it appears that radiation inhibits the utilization of carbohydrates by the cells, which are driven to get their energy from proteins.

The report also announces that the Duke of Bedford has felt compelled to resign from the office of president after more than thirty years service, and that he will be succeeded by Viscount Halifax.

Sir Basic Mayhew, vice-president, presiding at the general meeting of the Imperial Cancer Research Fund held on December 15, stated that the new building at Mill Hill will cost $£ 20,000$ and a further $£ 10,000$ will be required for equipment. The Fund has $£ 11,000$ in hand ; it requires $£ 19,000$. Referring to the relationship of the British Empire Cancer Campaign to the Imperial Cancer Research Fund, he said that the latter has raised large sums, and its policy is to use them in endowing and supporting institutions and individuals engaged in research work. Many of those to whom such grants have been made by the British Empire Cancer Campaign have been supplied with scientific material by the Imperial Cancer Research Fund. By this means, investigators have been enabled to start on their researches at a stage far in advance of that otherwise possible. Advice and suggestions are given whenever asked, facilities are given for research workers to use the Fund's laboratories, and tests are undertaken of cancer 'cures'. 